\title{
Miospore Biozonation of Cenomanian - Santonian Succession in FAMO-1 well, Gongola Sub Basin, Upper Benue Trough, Nigeria
}

\author{
AMIEWALAN, FO; *LUCAS, FA \\ Department of Geology, University of Benin, Benin City, Nigeria. \\ *Corresponding Author Email: amiewalanflorence@gmail.com,drfalucas@gmail.com
}

\begin{abstract}
The Early Cretaceous succession penetrated by Famo-1 well in Gongola sub Basin, Upper Benue Trough, Nigeria were analyzed for its palynological content. This investigation produced significant Pollen and Spore and the assemblage reveals the dominance of angiosperm Pollen grain and pteridophytes spore. Gymnosperm pollen was scarce and less varied. The studied interval penetrated a sequence of sandstone, sandy shale and mudstone occurring at different intervals in the studied section of the well. Established on the stratigraphic distribution of the palynomorphs recovered from Famo-1 well, three informal assemblage palynozones covering the Early Cretaceous were identified. The zones are: Assemblage Zones I \& II (Cenomanian); Assemblage Zone III (Turonian - Santonian). The different zones signifies a time stratigraphic unit comparable to the identified lithostratigraphic units penetrated by the well. The age (Cenomanian - Santonian) determinations are based on the known stratigraphic ranges of pollen and spores and their relative stratigraphic positions. Data from the studied well revealed that there is relatively higher frequency of the land derived pollen and spores compared to marine palynomorph abundance, which suggests a paralic condition of continental to shallow marine environment. The shallow marginal marine environment is further sustained by the presence of foraminifera test linings at some depths which are indicative of marine palaeoenvironment (inner neritic environment). Interpretations from the spore and pollen assemblages reveal sediment deposition took place in a wet to arid climate condition in marginal marine to nearshore environment.
\end{abstract}

\section{DOI: https://dx.doi.org/10.4314/jasem.v22i8.5}

Copyright: Copyright $\odot 2018$ Amiewalan and Lucas. This is an open access article distributed under the Creative Commons Attribution License (CCL), which permits unrestricted use, distribution, and reproduction in any medium, provided the original work is properly cited.

Dates: Received: 10 June 2018; Revised: 22 July: 2018; Accepted: 30 July 2018

Keywords: Palynology, Gongola sub Basin, Cretaceous, Famo-1 Well.

Palynology deals with the study of plant remains in sedimentary successions and their applications are useful in biostratigraphy. It has become valuable tools and universally accepted methods of evaluating the stratigraphy and source rocks potentiality of sedimentary basins. Palynological analysis provides data for determinations of ages, palynostratigraphy and palaeoenvironment of the studied parts of Gongola sub Basin in the Upper Benue Trough, Nigeria. Previous palynological studies for the Gongola Basin in the Upper Benue Trough indicated a Late Albian to Maastrichtian age by Lawal and Moullade (1986); Abubakar et al., (1989) for their contributions to the understanding of the age and stratigraphy. The aim of the present study is to establish the sedimentological and palynofloral characteristics of the Formations penetrated by Famo-1 Well, Gongola sub Basin, Benue Trough, Nigeria. These characteristics will be used in establishing the age, erect Palynofloral zonation and palaeoenvironment of deposition of the Formation. The objectives of the study involved the detailed sedimentological studies to build a lithologic model, identification of palynomorph (pollen and spore) abundance, their diversity and key taxa to produce biozonation scheme and establish the age, palaeoclimate and Palaeoenvironment of deposition.

\section{MATERIALS AND METHOD}

Description of study area: Famo -1 well was drilled in the Gongola Basin which forms part of the Upper Benue Trough. It has an estimated area of 27390.25 $\mathrm{km}^{2}$ and lies between longitude $10^{\circ} 42^{\prime} 43.8^{\prime \prime} \mathrm{E}$ and Latitude $10^{\circ} 07^{\prime} 03.9^{\prime \prime}$ N. Figure 1. The Benue Trough of Nigeria is an intracontinental Cretaceous basin of about 1000 kilometers in length, elongated in the NESW directions which overlies the Precambrian shield of the West African mobile belt (Obaje et al., (2006). Its southern limit is the northern boundary of the Niger Delta, while its northern limit is the southern boundary of the Chad Basin. Its structural origin is related to the opening of the South Atlantic Ocean (Benkhelil, (1982) and is part of series of Cretaceous rift basins that formed the West and Central African Rift System (WCARS) (Guiraud and Maurin (1992). The Benue Trough is considered most important and therefore, the most studied of all the Cretaceous sedimentary basins in Nigeria probably due to its peculiar 
formational history and its potentiality for hydrocarbon generation, ranking second to the oil prolific Niger Delta (Obaje et al., (1994). Reviews and the origin of the evolution of this linear NE-SW trending megastructure were provided by Benkhelil, (1982). The trough is arbitrarily divided into lower, middle and upper regions, and the upper region is further divided into the Gongola Basin, Yola arms and Lau Basin.

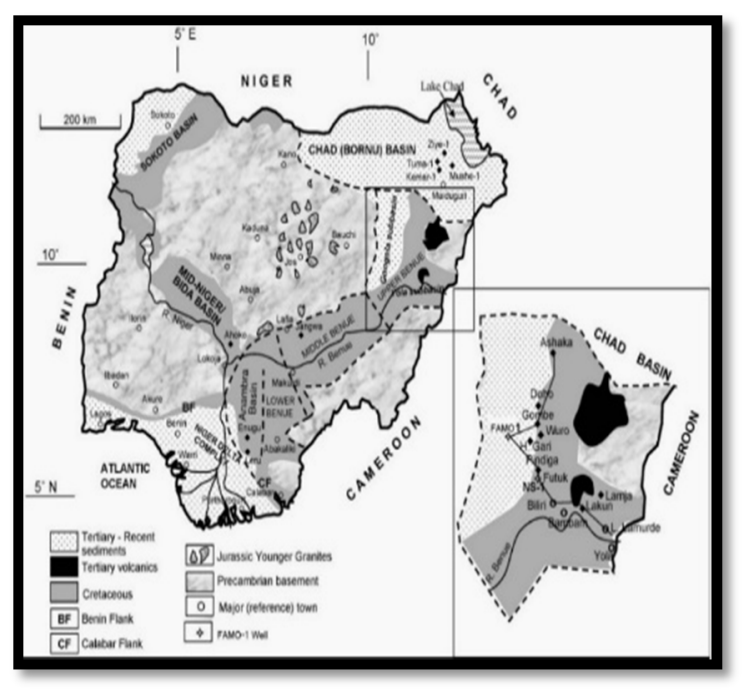

Fig 1: Generalized Geologic Map of Nigeria showing Area and Locations of Study. Modified from Obaje et al., (2005).

Stratigraphy of Benue Trough: The geology and stratigraphy of the three sub-basin segments have been well described and documented by Obaje et al., (2005). For the purpose of this study, the stratigraphy of the Gongola sub-basin will be discussed and adopted from the work of Obaje et al., (2005). The Stratigraphy of the Study area is as follows:

Bima Sandstone: The Bima Sandstone is the most extensive earliest continental sediments deposited on the floor of the entire basins of northeast Nigeria as a basal unit of the Cretaceous series soon after crustal rifting. It lies discomformably on the basement complex. The first major study on the Formation was carried out by Carter et al., (1963) and others such as those of Allix, (1983); Guiraud, (1990). The thickness of the Bima sandstone is between $100 \mathrm{~m}$ to over $3000 \mathrm{~m}$ of poorly sorted and thickly bedded feldspathic sandstone. Stages in the lithostratigraphic development of the clasts enabled division of the units into three members; the Lower Bima (Bima-1), the Middle Bima (Bima-2) and the Upper Bima (Bima-3). The palynological analysis of the outcropping beds of the Bima Sandstone dated the formation Late Aptian Early Albian.
Yolde Formation: The name Yolde Formation was proposed by Carter et al., (1963) for the transition beds recognized earlier by Falconer, (1911) between the Bima Group and the Pindiga Formation. According to Falconer, (1911) such transitional Formation is between the Muri sandstones and the marine Turonian above it. The Yolde Formation consists of a variable sequence of sandstones and shales. Thickness data for the Yolde Formation are scattered and insufficient to isopach. Cratchley and Jones (1965) assigned it an "Upper Cenomanian-Lower Turonian" age while Lawal and Moullade (1986) suggested a Late Albian to Early Cenomanian age for the Yolde Formation on the basis of its palynofossils.

Gongila Formation: The Formation is lithologically characterized by dark carbonaceous limestones and shales, intercalated with pale limestones and shales and minor sandstones. It is overlain conformably by the Fika Shale and lies conformably on the Yolde Formation. The Limestone of the Gongila Formation which occurs near the base is rich in fossils that indicate an Early Turonian age.

Pindiga Formation: The Pindiga Formation consists of marine shales with Limestones near the base. Dukul, Jessu, Sekule and Numanha sedimentary Formations has been mapped and are thought to be the lateral equivalents in the Yola Arm. The Pindiga Formation is fossiliferous and has yielded a lower Turonian fauna age.

Fika Shale: The Fika Shale consists of blue black shales, which are occasionally gypsiferous and which contain thin persistent limestones. The contacts with overlying Gombe Formation is not well exposed but may be unconformable and this justifies placing the Fika Shales in the Pre-Santonian.

Gombe Formation: The Gombe Sandstone outcrop is on the northwestern side of the upper Benue Trough and on the western side of the Gongola Basin. It consists of well bedded sandstones, grits, siltstones, flaggy sandstone and clays which become increasely ferruginous upwards. Ironstone bands are common and thin coals occur. Siltstones and flaggy sandstones form the greater part of the Gombe Sandstone. ShellBP geologists have dated the Gombe coal as late Senonian.

Kerri-Kerri Formation: This is composed of continental sequence, which dips northeast beneath the Chad Formation and lies unconformably on the folded Cretaceous sedimentations. They contain alternating layers of clayey grit, grit and sandstone with welldeveloped cross-bedding indicating lacustrine and 
deltaic environments and Carter et al., (1963) provisionally assigned it to Paleocene (Tertiary).

Chad Formation: This Formation is a variable sequence that includes all Quaternary sediments of lacustrine origin underlying the surface deposit over a vast area in the Chad Basin. The Chad Formation unconformably overlies the Fika Shale in some parts of the basin due to non-wide spread occurrence of both the Gombe Sandstone and Kerri-Kerri Formation which are mainly restricted to the southwest part of the Basin. The age is thought to be Pliocene-Quaternary (Tertiary).

Sample collection: Fifty (50) ditch cutting samples from $6980 \mathrm{ft}$. $-8330 \mathrm{ft}$. depth intervals of Famo-1 well were collected from Shell Petroleum Development Company. A detailed sedimentological description using the reflected light microscope was carried out to describing the lithology, color, texture (grain size, shape and sorting) and accessory minerals in the samples to generate the litholog. Thirty-five (35) samples were selected for palynological analysis.

Sample processing and analysis: From each depthinterval, about $20 \mathrm{gm}$ was weighed and following the standard techniques of Phipps and Playford (1984) of using hydrofluoric (40\%) and hydrochloric acid (35$38 \%$ ) to digest the silica and carbonates content of the sediments and the release of organic matter from the rock matrix. Heavy liquid separation and varying degrees of oxidation in Schultz's solution was employed. Samples were mounted on slides using polyvinyl alcohol (PVA) and permanently cure in UV light. The Slide were properly labelled and examined using transmitted light microscopes (Olympus binocular microscope) and snapshot were taken. See Plates (1 \& II) for the photomicrograph of the palynomorphs and Ancillary micro Fossils.

\section{RESULT AND DISCUSSION}

Palynomorphs recovered from interval $6980 \mathrm{ft}$. -8330 $\mathrm{ft}$. of Famo-1 well, yielded moderately preserved diverse assemblages of fossil palynomorphs. One hundred and fourteen (114) palynomorphs species were identified. The majority assemblage was dominated by angiosperm Pollen grain and pteridophytes spore. Gymnosperm pollen was scarce and less varied. Few foraminifera test lining, fungal spore and fresh water algae were recorved.

Palynomorph Range Chart: The palynomorph range chart were developed based on the first appearance datum (last downhole occurrence) and last appearance datum (first downhole occurrence) of miospore (pollens and spores). The palynomorphs recovered from the Famo -1 well are listed in Table 1

Table 1: Range chart of some important miospore recovered in Famo -1 well

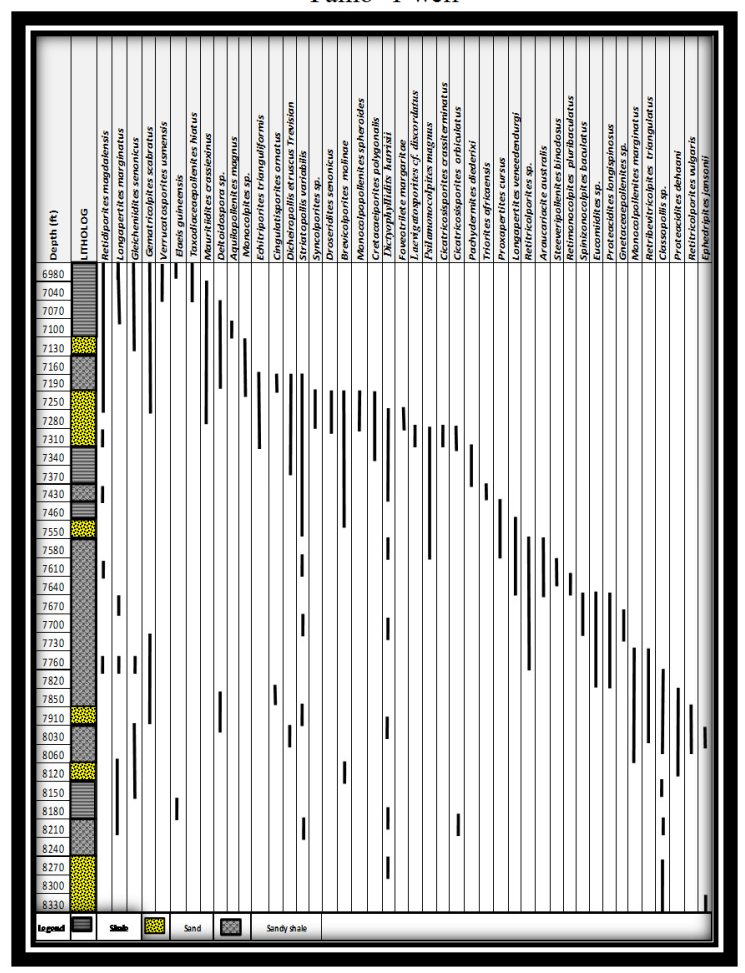

Araucariatcite australis, Cingulatisporites ornatus, Classopollis sp., Cicatricosisporites crassiterminatus, Cicatricosisporites orbiculatus, Concavisporites sp., Cyathidites sp., Dictyophyllidits harrisii, Deltoidospora sp., Droseridites senonicus, Deltoidospora psilostomata, Dictyophtllidites sp., Eucomiidites sp., Echitriporites trianguliformis, Ephedripites jansonii, Gleicheniidites senonicus, Longapertites marginatus, Longapertites microfoveolatus, Longapertites vaneendenburgi, Laevigatosporites discordatus, Mauritiidites crassiexinus, Monoporites sp., Monocolpopollenites spheroides, Graminidites annulatus, Proteacidites longispinosus, Polypodiaceoisporites retirugatus, Pachydermites diederixi, Proxapertites cursus, Proteacidites dehaani, Retidiporites magdalensis, Retidiporites miniporates, Taxodiaceaepollenites hiatus, Triorites africaensis, Steeveripollenites binodosus, Spinizonocolpites baculatus, Satuna enigmaticus, Verrutricolporites rotundipori, Verrucatosporites usmensis, Zonocostites ramonae and Zonosulcites parvus. Pollen and spores identified herein were also reported previously in the Cretaceous of Cote d'ivoire, Senegal, Sudan, Libya, Egypt, and other areas in central, West Africa and Brazil in South America. Also recovered are: Foraminifera test 
linings, fungal spores, Tasmanites sp., Pediastrum boryanum, Pediastrum duplex, Pediastrum simplex and Fungal Hyphae.

Palynological Zonation and Dating: Three informal biozones were established. Within each zone, data are presented in the stratigraphy sequence in which it is recognized and the species that have their first and last occurrence in the zone. The top of an underlying zone is equivalent to the base of the overlying zone. (Table 2 ). The biozones have been discussed from the base (oldest) to the top (youngest). Comparism of Palynomorphs assemblages with palynomorphs from other areas help to determine the age. The features in the present study in many respects are similar to an approximately coeval event described by Schrank and Ibrahim (1995); Jardine and Magloire (1965); Lawal and Moullade (1986). The event penetrated by Famo 1 well, according to biostratigraphic data, is Cenomanian - Santonian in age.

Table 2: Miospore biozonation recognized in Famo-1 well

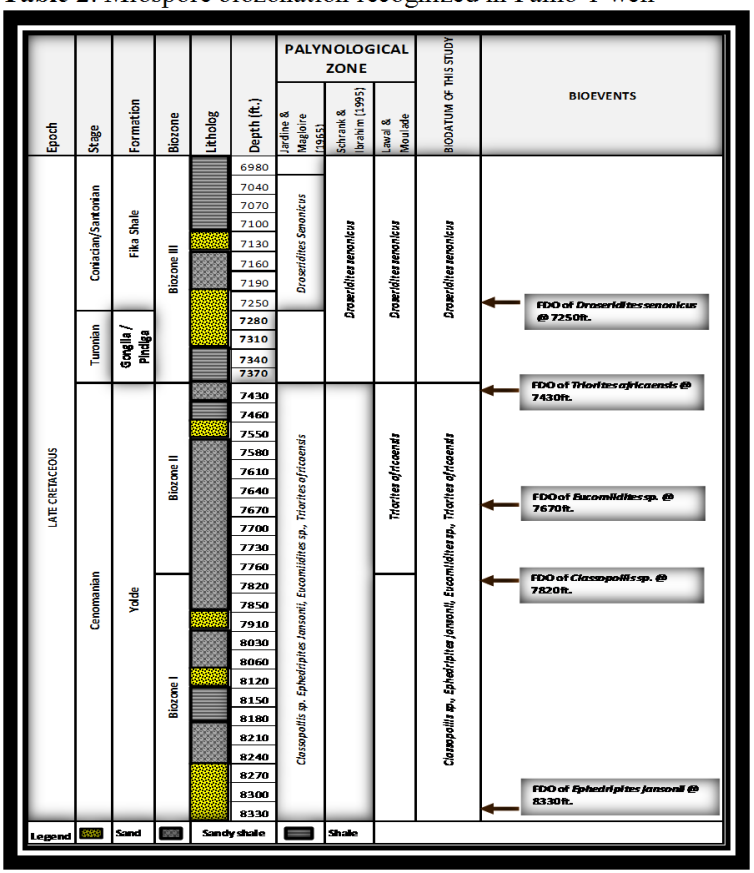

Biozone I: Stratigraphic Interval: $7820 \mathrm{ft} .-8330 \mathrm{ft}$. Sample numbers: 23 - 35: Diagnosis: The top of this zone is marked by the first downhole occurrence of Classopollis sp. at $7820 \mathrm{ft}$. The base of this zone is the base of the well and is marked by the first appearance datum of Ephedripites jansonii at $8330 \mathrm{ft}$. The species recorded within this zone include Monocolpollenites marginatus, Retribevitricolpites triangulates, Proteacidites dehaani and Retitricolporites vulgaris. Acme event of Classopollis sp. Other assemblage not included in the range chart include Psilatricolpites $s p$., Cyathidites sp., Syncolporites marginatus,
Distaverrusporites simplex, Dictyophyllidites sp. and Distaverrusporites simplex. The zone is also typified by the presence of fresh water algae of the genus Pediastrum. Other important elements of this zone are foraminifera test lining and fungal spore.

Age: The occurrence of Classopollis and Ephedripites in this zone are significant. Schrank and Ibrahim (1995); Thusu and Van Der (1985) had recorded Classopollis, Ephedripites among others as Aptian age. Uwins and Batten (1988) suggested that similar assemblage pointed to Aptian age while Jardine and Magloire (1965) had documented Ephedripites jansonii as Early Cenomanian age. However, the Albian Stage could not be confirmed in this study due to the absence of elaterate palynomorphs which are typical Albian marker species in low latitude West African basins. Accordingly, the zone is being dated Early Cenomanian age

Biozone II: Stratigraphic Interval: $7430 \mathrm{ft}$ - $7820 \mathrm{ft}$.: Sample numbers: 13 - 23: Diagnosis: The top of this zone is marked by the first downhole occurrence of Triorites africaensis at $7430 \mathrm{ft}$. The base of this zone is marked by the first downhole occurrence of Classopollis sp. at $7820 \mathrm{ft}$. The species recorded within this zone include Proxapertites cursus, Longapertites veneedenburgi, Retitricolporites sp., Araucariacite australis, Steeveripollenites binodosus, Retimonocolpites pluribaculatus, Spinizonocolpites baculatus, Eucomiidites sp., Proteacidites longispinosus and Gnetaceaepollenites sp.

Age: The occurrence of Eucomiidites sp. and Triorites africaensis in this zone are important. Jardine and Magloire (1965) had detailed Eucomiidites sp., as Early Cenomanian. Lawal and Moullade (1986) proposed Upper Cenomanian age in the Triorites africaensis zone assemblage in the Upper Benue Trough, Nigeria. Regali and Viana (1989) also proposed upper Cenomanian age using Triorites africaensis. Thus, Early - Late Cenomanian age was assigned to this biozone.

Biozone III: Stratigraphic Interval: $6980 \mathrm{ft}$. - $7430 \mathrm{ft.:}$ Sample numbers: 1 - 13: Diagnosis: This is the youngest zone identified in the studied well. The top of this zone is placed at the first sample analyzed at $6980 \mathrm{ft}$. The base of this zone is marked by the first downhole occurrence of Triorites africaensis at 7430 $\mathrm{ft}$. This assemblage shows frequency occurrence of Gematricolpites scabratus, Mauritiidites crassiexinus, Striatopollis variabilis and Dictyophyllidits harrisii. Other events that characterized this zone include Echitriporites trianguliformis, Cicatricosisporites crassiterminatus, Laevigatosporites cf. discordatus, Pachydermites diederixi, Monocolpopollenites spheroides, Cingulatisporites ornatus, 
Cretacaeiporites polygonalis, Foveotriletes margaritae, Dicheiropollis etruscus Trevisian, Verrucatosporites usmensis, Syncolporites sp., Droseridites senonicus and Brevicolporites molinae. The last appearance datum of Laevigatosporites $c f$. discordatus, Monocolpopollenites spheroides, Foveotriletes margaritae, Syncolporites sp., Deltoidospora sp. and Taxodiaceaepollenites hiatus characterized the zone. Graminidites annulatus also typified the zone but not recorded in the range chart. The zone is also described by the presence of freshwater alga - Pediastrum. Other important elements of this zone are foraminifera test lining and spot occurrence of fungal spore.

Age: The presence of Droseridites senonicus in the assemblage is of value in the dating of this zone. Droseridites senonicus has been documented as a Turonian-Early Senonian (Santonian) marker species by the following: Apaalse and Atta-Peters (2013); Lawal and Moullade (1986); Schrank and Ibrahim (1995). The presence of Echitriporites trianguliformis is another important pollen marker for dating the Senonian age. El Beialy, (1994) had also intimated that E. trianguliformis and Proteacidites types are important stratigraphic constituents of the Late Senonian sequences in the ASA region. In this study, comparison was based on these authors to use Droseridites senonicus and E. trianguliformis to date the zone as Turonian-Early Senonian (Santonian).

\section{Palaeoclimate and Paleoenvironmental} Interpretations: The palaeoenvironment is interpreted on the basis of the identified palynomorphs, in the light of their ecological preferences and also on the relative proportions of palynomorph groups. The interpretation indicates that the Cenomanian sediments were deposited in a near shore environment with vegetation fluctuating between humid / arid climate conditions. This is reflected from the palynoflora that have moderate record of xerophytes (Classopollis and Ephedripites). The presence of Conifer forests (Aurucariacites) are thought to flourish in the dry hinterlands during deposition of some horizons of this section. Chitinous foraminifera test lining also present are planispiral evolute which are of benthonic forms and their abundance indicates a flourishing environment, most probably an inner neritic environment indicative of occasional marine incursions. Thus further confirming the near-shore marine environment. The Turonian-Early Senonian (Santonian) sediments also suggest a fluctuation between wetland/drought in a humid/arid climate in a freshwater to brackish water environment. Verrucatosporites usmensis inhabit swampy freshwater to brackish water environment (Rull,
1997). The occurrence of pteridophytic spores (e.g. Deltoidospora) in this interval suggests the occurrence of wet vegetational lands near the depositional sites. Chitinous foraminifera test lining also indicates an inner neritic environment. The presence of fresh water algae such as Pediastrum which are characteristic of restricted marine conditions rather than normal open marine settings, with foraminifera test lining are indicative of marine incursion. Thus, the sediments of the Famo-1 well were deposited in a wet to arid climate in coastal or nearshore environment.

Plate 1: Photomicrographs of Some Palynomorphs Observed in Famo-1 well

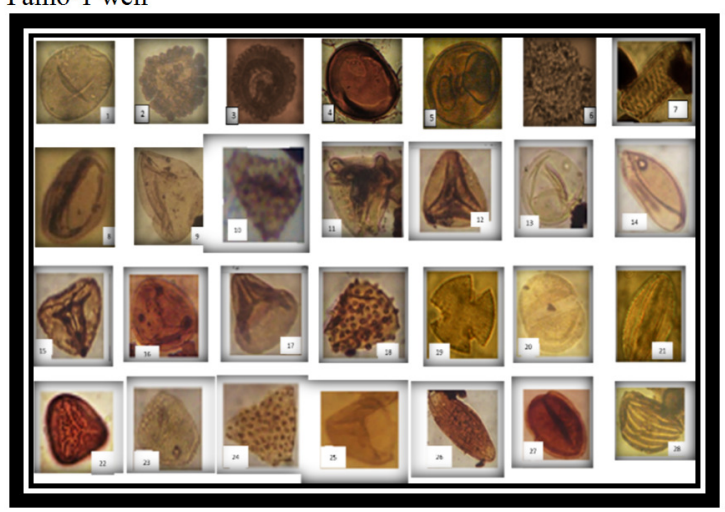

Explanation of plate 1: 1. Laevigatosporites aiscoratatus $2 \& 3$ Cingulatisporites ornatus 4\&5. Classopollis sp. 6. Droseridites senonicus 7. Ephedripites jansonii 8. Eucomiidites sp. 9. Longapertites vaneendenburgi 10. Echitriporites Trianguliformis 11. Triorites africaensis 12. Gleicheniidites senonicus 13. Graminidites annulatus 14. Longapertites microfoveolatus 15. Deltoidospora sp. 16.Foveotriletes margaritae 17.Dictyophyllidits sp. 18.Spinizonocolpites bucalatus 19.Retitricolpites vulgaris 20. Zonocostites ramonae 21.Striatopollis variabilis 22.Polypodiaceoisporites retirugatus 23. Retidiporites miniporates 24.Proteaccidites longispinosus 25. Elaeis guineensis 26. Ephedripites sp. 27. Aquilapollenites magnus 28. Cicatricosisporites crassiterminatus

Plate II: Atlas of Ancillary Micro Fossil from Famo-1 well

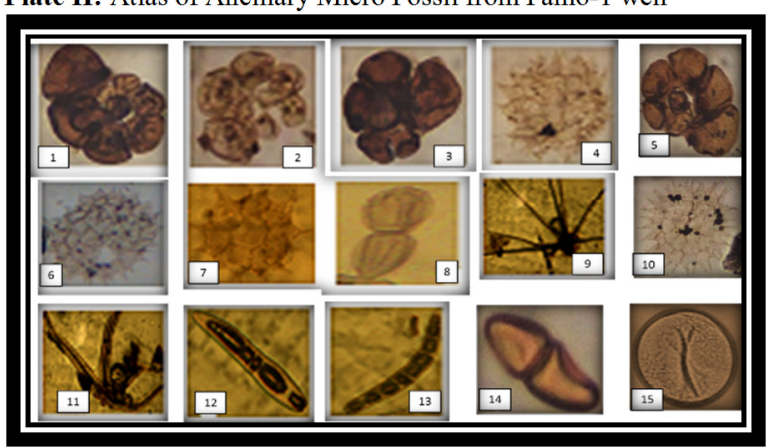

Explanation of plate II. 1 3\&5. Foraminifora Test Lining 8, 12, 13 \&14. Fungal spore 4\&10. Pediastrum duplex 6. Pediastrum boryanum 7. Pediastrum simplex 9\&11. fungal hyphae 15.Tasmanites

Conclusion: Palynological analysis of Famo-1 well shows that the angiosperm Pollen grain and pteridophytes spore dominated the assemblage. 
Gymnosperm pollen were few and less varied. Few foraminifera test lining, fungal spore and fresh water algae were also recorved. Age subdivision of the well section ranges from Early Cenomanian-Santonian. Three informal biozones were delineated from the well section. The sediments were deposited in a wet to arid climate in a coastal or nearshore environment.

Acknowledgement: The authors are grateful to Shell Petroleum Development Company, for the provision of the samples used for this project.

Acknowledgements are also made to Mrs. Patricia Ukeri of SPDC for her technical support during the quest for the solutions to the scientific questions encountered during this Project.

\section{REFERENCE}

Abubakar, MB; Luterbacher, HP; Ashraf, AR; Ziedner, R; Maigari, AS (1989). Late Cretaceous palynostratigraphy in the Gongola Basin (Upper Benue Trough, Nigeria). J. Afr. Earth Sci.60, 1927

Apaalse, LA; Atta-Peters, D (2013). CretaceousPalaeogene Palynology of the Keta-1 Well Offshore Keta Basin, Southeastern Ghana. World Appl. Sci. J. 23 (11), 1576-1583.

Benkhelil, J (1982). Benue Trough and Benue chain. Geol. Mag. 112, 155-168.

Carter, JD; Barber, WM; Tait, EA (1963). The Geology of parts of Adamawa, Bauchi, and Bornu province in N. E. Nigeria, Geol, Surv. Nigeria, Bull. 30, 1-99.

El Beialy, SY (1994). Palynostratigraphy and palynofacies analysis of some subsurface Cretaceous formations in the Badr El Dein (Bed 1-1) borehole, North Western Desert, Egypt. Neues Jahrbuch Geol. Palaeontol., Abhandlugen, 192(2), 133-149.
Jardine, S; Magloire, L (1965). Palynologie et starigraphie de Cretace des Bassins du Senegal et de Cote d'Ivoire: Mem. B.R.G.M., Coll. Int. Micropol., 32. 187-245.

Lawal, O; Moullade, M (1986). Palynological biostratigraphy of the Cretaceous sediments in the Upper Benue Basin, NE Nigeria. Rev. Micropaleontol., 29, 1-6.

Obaje, NG; Attah, DO; Opeloye, SA; Moumount, A (2005). Geochemical evaluation of hydrocarbon prospects of sedimentary basins in Northern Nigeria. Gechem. J. 40, 227-243.

Phipps, D; Playford, G (1984). Laboratory techniques for extraction of palynomorphs from sediments. Pap. Dept. Geol. Univ. Queensld., 11(1), 1-23.

Regali, MSP; Viana, CF (1989). Late Jurassic-Early Cretaceous in Brazilian sedimentary basins: correlation with the international standard scale, PETROBRAS, Rio de Janeiro, p. 95.

Rull, V (1997). Sequence analysis of Western Venezuelan Cretaceous to Eocene sediments using palynology: Chrono-paleoenvironmental and paleovegetational approaches. Palynol., vol. 21, p. 79-70.

Schrank, EC; Ibrahim, MI (1995). Cretaceous (AptianMaastrichtian) palynology of foraminifera- dated well (KRM-1, AG-18) in the northwestern Egypt, Berliner Geowiss., Abh. Reihe A. 177, 44.

Thusu, B; Van Der, JGE (1985). Early Cretaceous (Neocomian - Cenomanian) palynomorphs: $J$. Micropaleontology, 4 (1). 131-150.

Uwins PJR; Batten, DJ (1988). Early Cretaceous palynomorphs of northeast Libya. - ElArnauti, A. et. $A l(E d s$.$) .$ 